\title{
Hashimoto's Thyroiditis Revisited: The Association with Thyroid Cancer Remains Obscure
}

\author{
Michael K. McLeod, M.D., Mary E. East, M.D., Richard E. Burney, M.D., Jay K. Harness, M.D., and \\ Norman W. Thompson, M.D. \\ Department of Surgery, University of Michigan Medical Center, Ann Arbor, Michigan, U.S.A.
}

\begin{abstract}
Hashimoto's thyroiditis (HT) is an autoimmune disease of the thyroid associated with goiter and hypothyroidism. Although there exists a clear association between HT and lymphomas of the thyroid, the association between HT and thyroid cancer remains unclear. To evaluate this further, we retrospectively reviewed the pathology reports for all thyroidectomy specimens as well as the records of patients admitted to the University of Michigan Medical Center, Ann Arbor, Michigan, U.S.A., over a 10-yearperiod (1975-1985) with the diagnosis of HT or chronic lymphocytic thyroiditis (CLT). Eight hundred and nine pathologic diagnoses were recorded for 816 thyroidectomy specimens from 793 patients. Furthermore, 180 of 228 patient chart records were available for review. Only 128 patients satisfied our criteria for the diagnosis of HT. HT or CLT were diagnosed in $147(18.2 \%)$ of 809 thyroid specimens. HT occurred concurrently with thyroid cancer in $24 \%$ of all cases of HT, whereas, HT occurred concurrently with benign thyroid disease in $71 \%$ of all cases of HT in all thyroid specimens. Furthermore, HT was associated with 43 $(22 \%)$ of 195 cases of thyroid cancer. There were $111(87 \%)$ women and $17(13 \%)$ men of 128 patients whose charts were reviewed. The mean age was $49 \pm 14$ years. Ninety-eight $(77 \%)$ of the patients presented with goiters and $57(45 \%)$ presented with dominant thyroid masses, $38(67 \%)$ of which were solitary nodules. One patient $(0.8 \%)$ presented with a recurrent laryngeal nerve palsy (RLNP) and $12(9 \%)$ presented with tracheal compression. Only $29(38.2 \%)$ of 76 patients measured had positive antithyroglobulin (ATG) titers, whereas $65(87 \%)$ of 75 patients measured had positive antimicrosomal (AM) titers. Seventy $(55 \%)$ patients were evaluated with either a technetium or ${ }^{131}$ I thyroid scan. There was a heterogeneous pattern to the scan in $75 \%$ of these patients. Niney-one $(\mathbf{7 1 \%})$ patients were initially treated with thyroid suppression. However, $27(21 \%)$ required thyroidectomy for initial management. Ultimately, $60 \%$ required thyroidectomy and $37 \%$ required none. The major indication for surgical intervention was the presence of a dominant mass in $40(52 \%)$ of 77 patients. Only $17(13 \%)$ patients were found to have thyroid cancer concomitant with HT and $3(2 \%)$ had lymphoma with HT. The incidence of minimal (occult) cancer in a study of 100 consecutive autopsies at this institution was $13 \%$. We believe that these data suggest that the association of HT with thyroid cancer is relative, at best. It will be necessary to prospectively follow both a large group of patients with HT and a control group of patients without HT for the incidence of thyroid cancer in each before this issue can be appropriately addressed.
\end{abstract}

Hashimoto's thyroiditis (HT) is an autoimmune disease of the thyroid that is associated with goiter and hypothyroidism and

Presented at the International Association of Endocrine Surgeons in Sydney, Australia, September, 1987.

Reprint requests: Michael K. McLeod, M.D., University of Michigan Medical Center, 2920F Taubman Health Center, Box 0331, 1500 E. Medical Center Drive, Ann Arbor, Michigan 48109-0331, U.S.A. has a distinct prevalence in women [1]. There appears to be a clear association between HT and lymphoproliferative disorders including lymphomas of the thyroid $[2,3]$. However, the relationship between HT and thyroid carcinoma remains unclear. This remains true despite recent evidence to support the view that $\mathrm{HT}$ is a predisposing factor in the development of thyroid carcinoma [4]. Dailey et al. were the first to report a significant relationship between HT and thyroid carcinoma [5]. Subsequently, there has been considerable controversy over the accuracy of that finding with reports of incidences of thyroid carcinoma coexisting with HT ranging from $1 \%$ to $23 \%$ [6-14]. It is hypothesized that HT can be attributed to an inherited isolated defect in immunoregulation in which there is an organspecific defect in suppressor T-cell function $[15,16]$. Since such a defect will also adversely affect immune surveillance, it remains possible that, given this inherited genetic disposition, a patient susceptible to thyroiditis may also be more susceptible to the growth and development of a thyroid neoplasm. Moreover, in HT there is an inhibition of the production of iodinated organic compounds in the glands of these patients. Consequently, there is a reduction in the production of thyroxine or triiodothyronine and this course of events stimulates the feedback of increased secretion of TSH [1]. It is argued, therefore, that the chronic stimulation of the thyroid by elevated levels of TSH may, in addition to inducing goiter formation, initiate or promote the growth of thyroid neoplasms.

The purpose of this retrospective study was to further evaluate the relationship between HT and thyroid cancer in our clinical experience and to determine whether the incidence of coexistent HT in thyroid cancer was, indeed, significantly higher than the incidence of coexistent HT in benign thyroid disease.

\section{Methods}

The pathology reports for all operative thyroidectomy specimens obtained at the University of Michigan Medical Center, Ann Arbor, Michigan, U.S.A., over a 10-year-period beginning in January, 1975 and ending in December, 1985 were retrospectively reviewed. During this 10-year interval, 809 pathologic diagnoses were recorded for 816 thyroidectomy specimens submitted for pathologic evaluation. This data resulted from the 

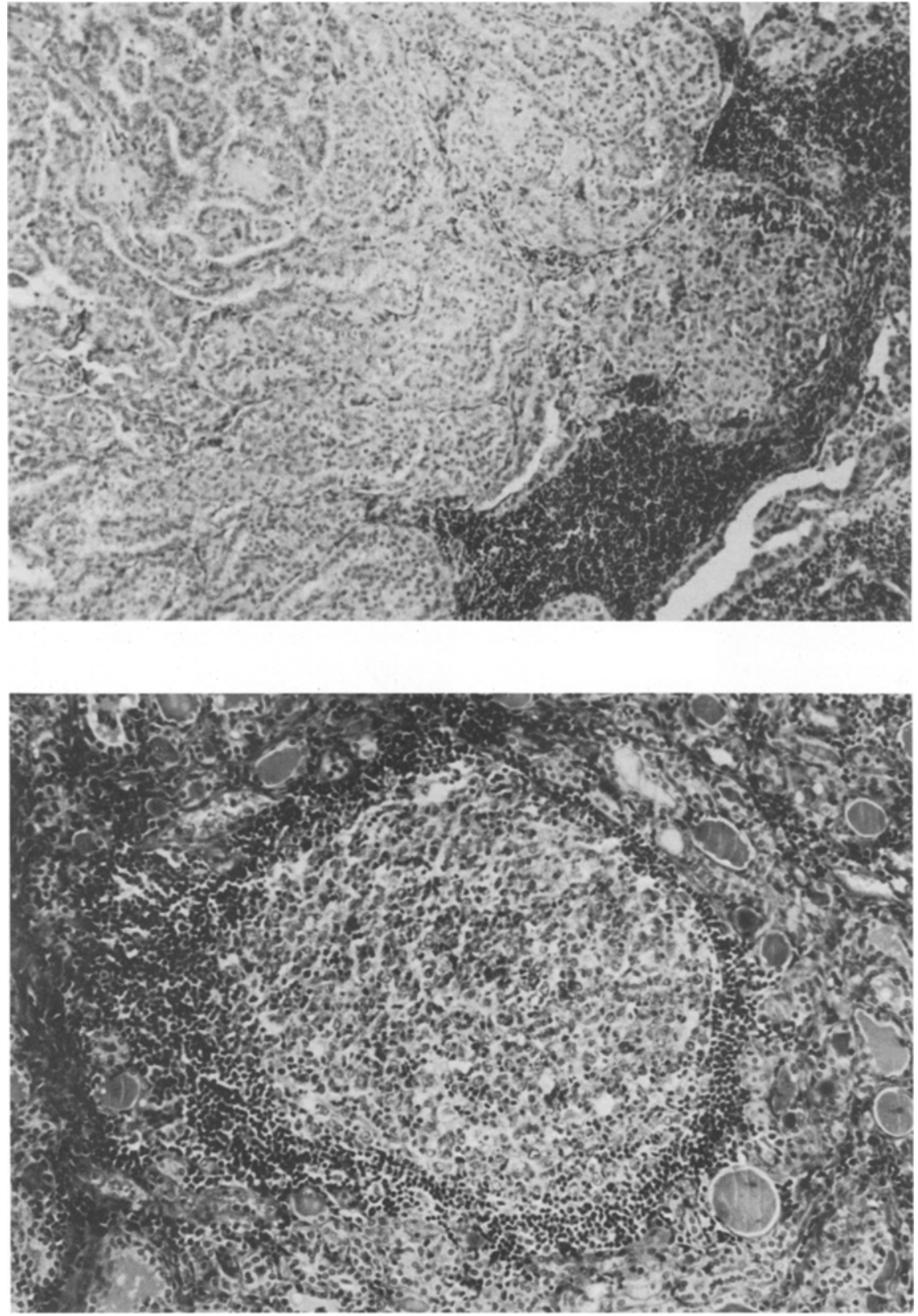

Fig. 1. Papillary cancer coexistent with diffuse lymphoplasmacytic infiltration and prominent germinal centers. The large cells with generous eosinophilic cytoplasm, irregular nuclei with prominent nucleoli are Hürthle cells that represent the eosinophilic metaplastic change associated with the follicular epithelium in Hashimoto's thyroiditis.
Fig. 2. An example of a germinal center in a case of Hashimoto's thyroiditis with prominent lymphocyte and plasmocyte infiltration. Askanazy or Hürthle cells are also present. management of 793 patients with thyroid disorders or clinical findings pertaining to the thyroid for which some form of thyroidectomy(ies) was indicated. The histologic criteria used to make the diagnosis of HT included diffuse lymphoplasmacytic infiltration (Figs. 1, 2), germinal centers (Fig. 2), enlarged epithelial cells with large nuclei and eosinophilic cytoplasm (Askanazy or Hürthle cells), fibrosis, distorted architecture, and small follicles depleted of thyroglobulin (Fig. 3). Review of the pathologic description of the microscopic findings was meticulous in order to distinguish between cases of nonspecific thyroiditis and/or focal thyroiditis associated with thyroid cancer. However, ultimately, the pathological diagnosis was accepted as that recorded on the final pathology report.
During a concurrent time interval, 228 patients were identified by the Medical Records department of the University Hospital as having been coded with the diagnosis of HT. The medical records of 180 of these were available for review. One hundred and twenty-eight patients satisfied our criteria for the diagnosis of HT. These criteria included: hypothyroidism associated with a thyroid goiter; positive thyroid antithyroglobulin (ATG) and/or antimicrosomal (AM) antibodies associated with a thyroid mass or hypothyroidism; or classic pathologic findings of HT in the surgical specimen if a thyroidectomy was performed. Differences between frequency distributions observed were tested for using the chi-square test for independent samples [17]. $P \leq 0.05$ was accepted as statistically significant. 


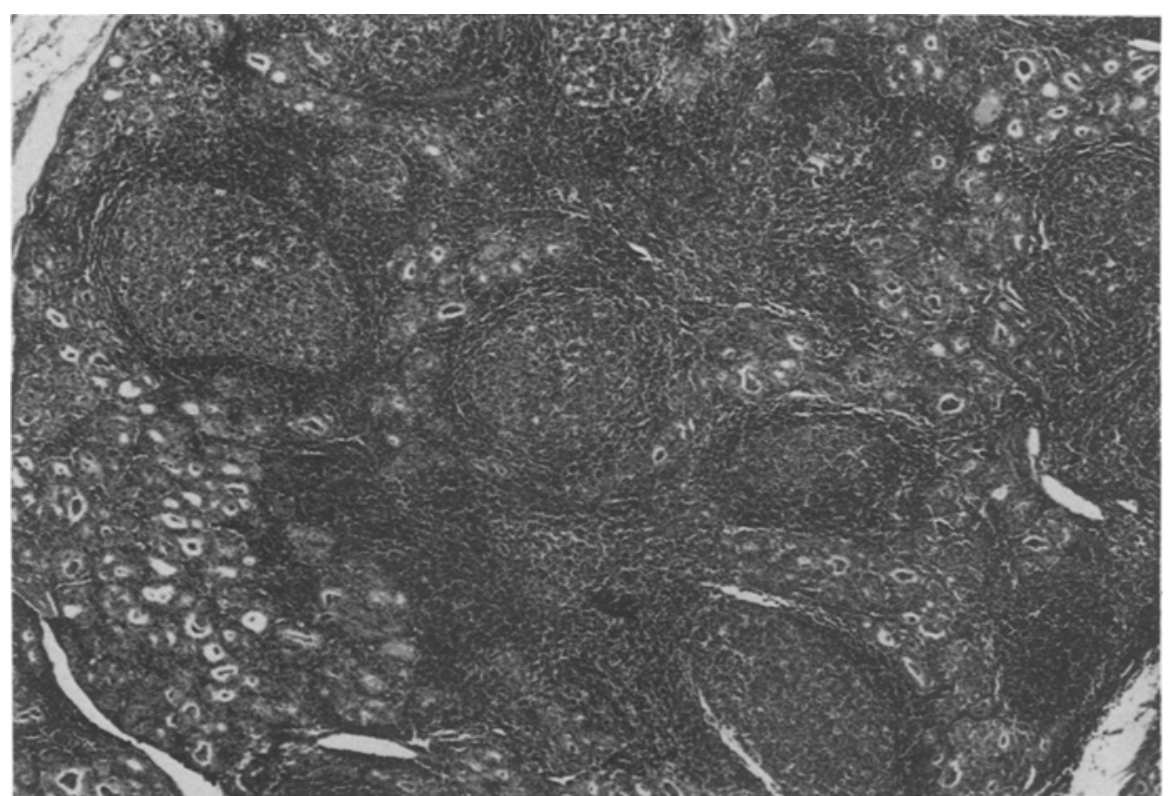

Fig. 3. An example of Hashimoto's thyroiditis demonstrating germinal center, distorted architecture, and loss of colloid or depleted follicles.
Table 1. Summary of all thyroidectomy procedures during the period 1975-1985.

\begin{tabular}{llc}
\hline Operation & No. of cases & \% of all procedures \\
\hline Lobectomy and/or isthmusectomy & 399 & 48.9 \\
Subtotal thyroidectomy & 226 & 27.7 \\
Total thyroidectomy & 120 & 14.7 \\
Completion thyroidectomy & 41 & 5.0 \\
Near total thyroidectomy & 20 & 2.5 \\
Nodulectomy & 10 & 1.2 \\
Total & 816 & 100 \\
\hline
\end{tabular}

\section{Results}

\section{Pathology Review}

Seven hundred and ninety-three patients underwent 816 thyroidectomies. These 816 thyroidectomies were comprised of $120(14.7 \%)$ total thyroidectomies, $20(2.5 \%)$ near total thyroidectomies, 41 (5.0\%) completion thyroidectomies, $226(27.7 \%)$ subtotal thyroidectomies, 399 (48.9\%) lobectomies and/or isthmusectomies, and $10(1.2 \%)$ nodulectomies (Table 1). Eight hundred and nine pathologic diagnoses were reported based on the pathologic evaluation of the above thyroidectomy specimens. One hundred and ninety-five (24\%) of 809 were thyroid carcinomas, $165(84.6 \%)$ of which were well-differentiated thyroid carcinomas (Table 2). There were $10(5.1 \%)$ lymphomas of the thyroid, $9(4.6 \%)$ pure medullary thyroid carcinomas, 4 (2.1\%) anaplastic or undifferentiated thyroid carcinomas as well as 3 squamous cell thyroid carcinomas, and 2 cases each of mixed medullary/papillary and metastatic thyroid carcinomas, respectively.

A diagnosis of either HT or chronic lymphocytic thyroiditis (CLT) was made either individually or concurrently with another diagnosis in $147(18.2 \%)$ of 809 pathologic cases reviewed. Although it is possible to distinguish between HT and CLT based on strictly pathologic criteria (for example, the absence of Askanazy or Hürthle cells in the latter), for the purpose of
Table 2. Summary of the incidences of thyroid carcinoma in all thyroidectomy specimens during the period 1975-1985.

\begin{tabular}{lccc}
\hline $\begin{array}{l}\text { Thyroid cancer- } \\
\text { Cell type }\end{array}$ & $\begin{array}{l}\text { No. of } \\
\text { cases }\end{array}$ & $\begin{array}{l}\text { \% of thyroid } \\
\text { cancer }\end{array}$ & $\begin{array}{l}\text { \% of all } \\
\text { specimens }\end{array}$ \\
\hline Papillary & 143 & 73.3 & 17.7 \\
Hürthle & 12 & 6.2 & 1.5 \\
Follicular & 10 & 5.1 & 1.2 \\
Lymphoma & 10 & 5.1 & 1.2 \\
Medullary & 9 & 4.6 & 1.1 \\
Anaplastic & 4 & 2.1 & 0.5 \\
Squamous cell & 3 & 1.5 & 0.4 \\
Metastatic & 2 & 1.0 & 0.2 \\
Medullary/papillary & 2 & 1.0 & 0.2 \\
$\quad$ Total & 195 & 100 & 24.0 \\
\hline
\end{tabular}

this review both entities were combined and considered collectively as HT. Hashimoto's thyroiditis was diagnosed in association with concurrent thyroid carcinoma in $43(29.3 \%)$ of 147 pathologic cases with HT.

Thirty-six cases $(83.7 \%)$ of HT concurrent with thyroid carcinoma were due to well-differentiated thyroid carcinoma (Table 3$)$. Four cases $(9.3 \%$ ) were due to thyroid lymphoma. On the other hand, a total of $104(70.7 \%)$ of 147 cases of HT were associated with benign thyroid disease. This occurred in an enlarged thyroid gland with either a single thyroid nodule or multiple nodules in virtually all cases (Table 4). Overall, HT was associated with $43(22.1 \%)$ of 195 cases of thyroid cancer in this series, whereas HT was associated with 104 (16.9\%) of 614 cases of benign thyroid disease in the series. There was no statistically significant difference between the frequency distribution of HT associated with thyroid carcinoma versus benign thyroid disease $(p>0.10)$.

To examine further the association of HT with concurrent well-differentiated thyroid carcinoma, it was observed that 30 (21.0\%) of 143 papillary thyroid carcinomas were associated with concurrent HT. Furthermore, papillary thyroid carcinoma represented $70 \%$ of all the cases of $\mathrm{HT}$ diagnosed to be 
Table 3. Summary of all surgical specimens with concurrent thyroid carcinoma and Hashimoto's or chronic lymphocyte thyroiditis during the period 1975-1985.

\begin{tabular}{|c|c|c|c|}
\hline Histology $y^{a}$ & $\begin{array}{l}\text { No. of } \\
\text { cases }\end{array}$ & $\begin{array}{l}\% \text { of cases } \\
\text { with } \\
\text { concurrent } \\
\text { cancer }^{b}\end{array}$ & $\begin{array}{l}\% \text { of all } \\
\text { cases of } \\
\text { thyroiditis }\end{array}$ \\
\hline Papillary and thyroiditis & 30 & 69.8 & 20.4 \\
\hline Follicular and thyroiditis & 5 & 11.6 & 3.4 \\
\hline Lymphoma and thyroiditis & 4 & 9.3 & 2.7 \\
\hline Hürthle cell and thyroiditis & 1 & 2.3 & 0.7 \\
\hline Medullary and thyroiditis & 1 & 2.3 & 0.7 \\
\hline Anaplastic and thyroiditis & 1 & 2.3 & 0.7 \\
\hline Metastatic and thyroiditis & 1 & 2.3 & 0.7 \\
\hline $\begin{array}{l}\text { Total cases of malignant } \\
\text { disease and thyroiditis } \\
\text { Total cases of } \\
\text { thyroiditis }\end{array}$ & 147 & 100 & 29.3 \\
\hline
\end{tabular}

aAll thyroid carcinomas with Hashimoto's or chronic lymphocytic thyroiditis.

${ }^{b}$ Concurrent thyroid cancer and Hashimoto's thyroiditis.

Table 4. Summary of all surgical specimens with Hashimoto's or chronic lymphocytic thyroiditis in benign thyroid disease.

\begin{tabular}{|c|c|c|c|}
\hline Histology & $\begin{array}{l}\text { No. of } \\
\text { cases }\end{array}$ & $\begin{array}{l}\% \text { of cases with } \\
\text { thyroiditis and } \\
\text { benign lesion }\end{array}$ & $\begin{array}{l}\% \text { of cases of } \\
\text { thyroiditis }\end{array}$ \\
\hline Hashimoto's thyroiditis & 74 & 71.2 & 50.3 \\
\hline \multicolumn{4}{|l|}{ Chronic lymphocytic } \\
\hline Adenoma and thyroiditis ${ }^{a}$ & 7 & 6.7 & $\begin{array}{l}4.0 \\
4.8\end{array}$ \\
\hline Goiter and thyroiditis & 6 & 5.8 & 4.1 \\
\hline \multicolumn{4}{|l|}{$\begin{array}{l}\text { Diffuse and adenomatous } \\
\text { hyperplasia and }\end{array}$} \\
\hline \multicolumn{4}{|l|}{ Colloid nodules and } \\
\hline thyroiditis & 3 & 2.9 & 2.0 \\
\hline \multicolumn{4}{|l|}{ Hürthle cell tumor and } \\
\hline \multicolumn{4}{|l|}{$\begin{array}{l}\text { Total cases of benign } \\
\text { disease and }\end{array}$} \\
\hline thyroiditis & 104 & 100 & 70.8 \\
\hline thyroiditis & 147 & & \\
\hline
\end{tabular}
itis.

'Thyroiditis = Hashimoto's and/or chronic lymphocytic thyroid-

associated with thyroid carcinoma. Five (50\%) of 10 follicular thyroid carcinomas were associated with HT. One (8.3\%) of 12 Hürthle cell thyroid carcinomas were similarly associated with HT. In comparison to these distributions for well-differentiated thyroid carcinoma, 4 (40\%) of 10 lymphomas of the thyroid were associated with HT.

The incidence of thyroid nodules in this series was 184 (22.7\%) of 809 cases. One hundred and sixty-five (89.7\%) of 184 thyroid nodules were colloid, $8(4.3 \%)$ of 184 were follicular. The remainder were either atypical, cellular, or nonspecific thyroid nodules. Only $3(1.6 \%)$ of 184 thyroid nodules were observed to contain concomittant HT. It should be noted here that cases with nonencapsulated nodules found in glands with diffuse involvement demonstrating findings that were consistent with HT were simply considered to represent HT.
Table 5. Hashimoto's thyroiditis: Metabolic status.

\begin{tabular}{lcc}
\hline & Clinical criteria & Thyroid function tests \\
Metabolic status & $\mathrm{n},(\%)$ & $\mathrm{n},(\%)$ \\
\hline Euthyroid & $74,(58.7 \%)$ & $53,(50 \%)$ \\
Hypothyroid & $46,(36.5 \%)$ & $50,(47.2 \%)$ \\
Hyperthyroid & $6,(4.8 \%)$ & $3,(2.8 \%)$ \\
Total & $126,(100 \%)$ & $106,(100 \%)$ \\
\hline
\end{tabular}

\section{Patient Chart Review}

There were $111(87 \%)$ women and $17(13 \%)$ men of 128 patients who satisfied the criteria for the diagnosis of HT. This represents a female to male ratio of $7: 1$ for this series. The mean age for women was $39 \pm 19$ years and ranged from 4 to 80 years. The mean age for men was $45 \pm 16$ years and ranged from 15 to 69 years. The mean duration of follow-up for this group of patients was $4.0 \pm 4.4$ years. Eight (6.3\%) of 128 patients had a positive past medical history for having received prior head and neck irradiation. However, $7(87.5 \%)$ of 8 patients with a history of previous head and neck irradiation had HT alone (1 patient had laboratory values for thyroid function in the hyperthyroid range, although the patient was clinically euthyroid). Only $1(12.5 \%)$ of 8 patients with a history of previous head and neck irradiation had concurrent HT and thyroid cancer.

Ninety-eight $(76.6 \%)$ of the patients were found to have goiters on presenting physical examination, $85(87.6 \%)$ of which were bilateral. Palpable thyroid nodule(s) were noted in 57 $(44.5 \%), 38(66.7 \%)$ of which were solitary and $19(33.3 \%)$ of which were multiple. One patient $(0.8 \%)$ of 128 presented with a recurrent laryngeal nerve palsy and was subsequently proven to have thyroid cancer concurrent with HT. Twelve (9.4\%) of 128 patients presented with either tracheal deviation or compression, $2(16.7 \%)$ of which were subsequently proven to have thyroid cancer concurrent with HT.

The clinical diagnosis regarding metabolic status was noted in 126 patients. Seventy-four patients $(58.7 \%)$ were noted to be euthyroid, $46(36.5 \%)$ were noted to be hypothyroid, and 6 (4.8\%) were noted to be hyperthyroid based on purely clinical criteria. This compared with thyroid function studies consistent with a euthyroid status in $53(50 \%)$ of 106 patients, a hypothyroid status in $50(47.2 \%)$, and a hyperthyroid status in $3(2.8 \%)$ (Table 5).

Only $29(37.2 \%)$ of 78 patients measured had positive serum antithyroglobulin antibodies, whereas $64(82.1 \%)$ had positive serum antimicrosomal antibodies.

Seventy patients $(55.6 \%)$ of 126 were evaluated with either a $99 \mathrm{~m}$ technetium or ${ }^{131}$ I thyroid scan. A heterogeneous scan was observed in $75 \%$ of those studied. Eleven (61\%) of 18 patients, for which there was specific data, had increased uptake on thyroid scan. In $29(44.6) \%$ of 65 thyroid scans a nodule was identified. Twenty-three (79.3\%) of 29 thyroid nodules on thyroid scan were cold, whereas $5(17.2 \%)$ were hot and in one the functional status was not stated. The incidence of thyroid carcinoma was $6(31.6 \%)$ of 19 cold nodules. Seven $(36.8 \%)$ of 19 cold nodules were colloid nodules, $2(10.5 \%)$ cold nodules were benign adenomas, and $2(10.5 \%)$ cold nodules were lymphomas of the thyroid. There was no instance of thyroid carcinoma seen in a hot nodule in this group of patients. One 
Table 6. Summary of initial management in patients with Hashimoto's thyroiditis.

\begin{tabular}{lcc}
\hline Treatment & No. of cases & $\%$ of total \\
\hline TSH suppression & 91 & 73 \\
Subtotal thyroidectomy & 24 & 19 \\
Total thyroidectomy & 3 & 2 \\
No treatment & 3 & 2 \\
Other & 4 & 3 \\
Total & 125 & 100 \\
\hline
\end{tabular}

(33.3\%) of 3 hot nodules was a lymphoma of the thyroid and the remaining 2 hot nodules were benign thyroid lesions.

Ninety-one $(72.8 \%)$ of 125 patients were initially treated with thyroid replacement (TSH suppression). However, 27 (21.6\%) patients required thyroidectomy ( 24 subtotal thyroidectomies and 3 total thyroidectomies) for the initial management of their HT. Ultimately, $77(60.2 \%)$ of 128 patients with HT required thyroidectomy to successfully manage their thyroiditis. Fortysix $(37 \%)$ of 124 patients required no surgical intervention and 4 (3.2\%) underwent needle biopsy which either confirmed or established the diagnosis of HT (Table 6).

The major indication for thyroidectomy in this group of patients was the presence of a dominant mass in $40(51.9 \%)$ of 77 patients, $31 \%$ of which had thyroid carcinoma (Table 7). Two (6.9\%) of 29 patients with dominant masses as an indication for thyroidectomy had lymphoma of the thyroid and $18(62 \%)$ with dominant masses as the indication for thyroidectomy had benign thyroid disease.

Ninety-six (75\%) of 128 patients had HT as their sole diagnosis. There were $5(3.9 \%)$ patients with findings consistent with Hashitoxicosis, however, 3 of these patients had past medical histories of Graves' disease and probably represented Graves' disease with concurrent HT. Five patients (3.9\%) had goiters with hypothyroidism both clinically and biochemically as the sole criteria for their diagnosis. Two patients $(1.6 \%)$ had HT associated with benign adenomas. Only $17(13.3 \%)$ patients of this group of 128 were found to have thyroid carcinoma concomitant with their HT and $3(2.3 \%)$ had lymphoma of the thyroid concomitant with their HT (Table 8). The incidence of minimal (occult) thyroid carcinoma in a study of 100 consecutive autopsies at this institution was $13 \%$ [18].

\section{Discussion}

Endemic goiter is the most common thyroid disease today [19]. The addition of iodine to the diet has actually increased the incidence of Hashimoto's thyroiditis, which falls into the category of endemic goiter. This is supported by the observation that lymphocytes are not found in the thyroid glands of iodinedeficient endemic goiters. The introduction of iodine into the diet in an endemic area is, however, accompanied by increasing lymphocytic infiltration with the subsequent development of HT [19]. This response is apparently preconditioned in a certain portion of the population by an underlying inherited or acquired biochemical defect in the thyroid, thus, impairing organic iodine binding. These facts may well explain why HT is probably the most common cause of diffuse goiter in the United States with an incidence in autopsy specimens of $2 \%$ [20, 21]. Furthermore, the incidence of HT has been documented to be increasing with
Table 7. Indications for thyroidectomy among patients with Hashimoto's thyroiditis.

\begin{tabular}{lcc}
\hline Indication & No. of cases & $\%$ of total \\
\hline Dominant mass & 40 & 52 \\
Compressive symptoms & 8 & 10 \\
Increasing size & 7 & 9 \\
Medical failure & 5 & 7 \\
Cosmesis & 3 & 4 \\
Airway obstruction & 1 & 1 \\
Other & 13 & 17 \\
Total & 77 & 100 \\
\hline
\end{tabular}

Table 8. The distribution of clinical diagnoses seen in patients with Hashimoto's thyroiditis.

\begin{tabular}{lc}
\hline Clinical diagnosis & No. of cases, $(\%)$ \\
\hline Hashimoto's ${ }^{a}$ & $106,(83)$ \\
Thyroid carcinoma & $17,(13)$ \\
Lymphoma & $3,(2)$ \\
Thyroid adenoma & $2,(2)$ \\
Total & $128,(100)$ \\
\hline
\end{tabular}

${ }^{a}$ Includes patients with Graves' Disease (3), goiter and HT (5), and probable Hashitoxicosis (2).

the highest incidence occurring in women aged 20-39 years [22]. The above simply highlights the fact that the incidence of HT is much higher than is appreciated, largely because the majority of these patients remain asymptomatic or insufficiently symptomatic to seek medical advice. Therefore, the 128 patients reviewed in this series are believed to represent a highly select group of patients with problematic or symptomatic HT. As such, the $13 \%$ incidence of thyroid carcinoma in this group of patients with HT represents an overestimate of the frequency distribution of thyroid cancer occurring in HT. Regardless, this incidence is no greater than the incidence observed for minimal occult thyroid carcinoma in 100 consecutive autopsies performed at the University of Michigan Medical Center [18].

The findings that only 2 patients from this series of 128 patients with HT had an associated benign adenoma and that the incidence of HT was observed to be only $2-5 \%$ in thyroidectomy specimens with either benign adenoma, multinodular goiter, or colloid nodules suggests that it may be misleading if this group is used as a control or comparison group to examine the incidence of HT in thyroid cancer versus benign thyroid disease. This is further suggested by the fact that the incidence of HT in all benign thyroid disease among the thyroidectomy specimens was $104(17 \%)$ of 614. Consequently, using colloid nodules as an internal control for benign disease with which to compare the incidences of HT in cancer and benign thyroid disease as utilized by Ott et al. [4] may not be appropriate. However, this point will require further investigation.

Although Hashimoto's thyroiditis associated with thyroid cancer has been documented in 3 girls with ages ranging from 10 to 14 years [23], the finding of such a young patient in the female group perhaps deserves comment. The youngest patient was a 4-year-old girl who had juvenile onset diabetes mellitus, a negative family history and a negative past medical history for other autoimmune diseases. She was euthyroid at presentation with a bilateral, diffuse goiter and positive antimicrosomal 
antibodies. Initially, she received no treatment. However, because of the increasing size of her goiter, in the absence of any discrete mass or nodule, she was placed on thyroid medication. During a 9-year follow-up she became hypothyroid and remained on thyroid medication until she was lost to follow-up. This case is consistent with the clonal-selection theory of immunity and highlights the precariousness of depending on the selective unresponsiveness of T-lymphocytes (suppressor Tcell lymphocyte function) to maintain tolerance to "self" or autoantibodies [24]. Since the difference between the immune response in the fetus and the adult is merely quantitative, it is not unexpected that autoimmune disease can theoretically occur at any age.

Moreover, this patient with autoimmune disease involving her pancreas (islet cells) as well as her thyroid suggests that she should be carefully observed and screened for other organspecific autoimmune diseases elsewhere, for example, her adrenal cortex (Schmidt's syndrome). As suggested by Clark et al., this child would need to be watched and screened carefully for Addison's disease in order to prevent inadvertent adrenal crisis [25].

It is apparent from this review that patients with HT who are at risk for harboring concurrent thyroid cancer are those who are found to have a cold or nonfunctioning thyroid nodule on ${ }^{99} \mathrm{~m}$ technetium or ${ }^{131} \mathrm{I}$ scan or those who present with a dominant thyroid mass that is nonsuppressible on adequate TSH suppression. Thyroid carcinoma was found in $32 \%$ of all cold thyroid nodules and $31 \%$ of all dominant thyroid masses in this series. These findings agree with the observations made by others $[25,26]$ and are consistent with the incidence of thyroid carcinoma in most clinical settings when associated with a solitary cold nodule [27-29]. In addition to a thyroid scan, Clark et al. recommend obtaining an ultrasound of the thyroid in evaluating patients with HT with a thyroid mass since, in their experience, cystic nodules of the thyroid in patients with HT are rarely malignant and are most often successfully managed by percutaneous aspiration [30].

The indications for thyroidectomy in this series included: a dominant mass (discrete, clinically suspicious thyroid nodule or mass), signs of compression on the trachea and/or esophagus, a diffusely enlarged thyroid that is increasing in size despite TSH suppression, the failure of a thyroid nodule to regress while on thyroid replacement, airway obstruction, or miscellaneous factors such as hyperthyroidism secondary to autonomous function or a cosmetically unattractive neck mass.

In the absence of any of these findings or the demonstration of a dominant or solitary cold nodule, the management of patients with HT should include careful follow-up after the patient is on a stable regimen of adequate thyroid replacement (TSH suppression).

We believe that this retrospective study of clinical and pathologic material does not support the hypothesis that HT is a predisposing factor for thyroid carcinoma. It is concluded that the association of HT with thyroid carcinoma is relative, at best, and that it will be necessary to prospectively follow both large populations of patients with and without HT before this issue can be resolved.

\section{Résumé}

La thyroïdite d'Hashimoto (TH) est une maladie autoimmune de la thyroïde qui provoque goitre et hyperthyroïdisme. Bien que l'association entre TH et lymphome de la thyroïde soit bien établie, celle entre $\mathrm{TH}$ et cancer de la thyroïde reste confuse. Pour essayer de mieux élucider cette question, les auteurs ont revu rétrospectivement les comptes rendus d'histologie de toutes les pièces de thyroïdectomie, et les dossiers de tous les patients admis pendant la période 1975-1985 avec le diagnostic de $\mathrm{TH}$ ou de thyroïdite lymphocytique chronique (TLC). Il y avait 809 diagnostics enrégistrés pour 816 pièces de thyroïdectomie provenant de 793 patients. En outre, 180 dossiers sur 228 étaient exploitables. Cent-vingt-huit patients seulement remplissaient les conditions diagnostiques de TH. TH ou TLC étaient diagnostiquées dans 147 (18.2\%) pièces sur 809. La TH était associée avec un cancer dans $24 \%$ de tous les cas de TH, alors que la $\mathrm{TH}$ était associée à une maladie bénigne de la thyroïde dans $71 \%$ des cas de TH. La TH était présente dans 43 (22\%) sur 195 des cas de cancer de la thyroïde. Il y avait 111 (87\%) femmes et 17 hommes (13\%). L'âge moyen était de $49 \pm$ 14 ans. Quatre-vingt-huit patients (77\%) avaient un goitre et 57 $(45 \%)$ une masse, $38(67 \%)$ étant un nodule solitaire. Un patient $(0.8 \%)$ avait d'emblée une paralysie récurrentielle et $12(9 \%)$ avaient une compression trachéale. Vingt-neuf (38.2\%) patients seulement sur 76 avaient des anticorps antithyroglobuline thyroïdiens, et $67(87 \%)$ des 75 patients avaient des anticorps antimicrosomiaux. Soixante-dix patients (55\%) ont eu une scintigraphie au technetium ou à 1'I 131: la thyroïde était hétérogène pour $75 \%$ d'entre eux. Quatre-vingt un patients $(71 \%)$ ont eu une hormonothérapie suppressive en premier, alors que $27(21 \%)$ ont eu une thyroïdectomie première. Ultérieurement, $60 \%$ des patients ont été thyroïdectomisés. L'indication principale de la chirurgie était la présence d'une masse, trouvée chez 40 (52\%) des 77 patients. Seuls 17 (13\%) patients avec une $\mathrm{TH}$ avaient un cancer simultané de la thyroïde; $3(2 \%)$ avaient un lymphome associé à une TH. La fréquence de cancer occulte dans une étude de 100 autopsies consécutives dans notre établissement était de 13\%. Nous pensons que ces résultats suggèrent que l'association $\mathrm{TH}$ cancer de la thyroïde n'est que fortuite. Il est nécessaire de suivre prospectivement un grand nombre de patients, divisés en 2 groupes, les uns avec $\mathrm{TH}$, les autres sans, pour déterminer avec précision l'incidence de cancer dans chaque groupe avant de résoudre ce problème.

\section{Resumen}

La tiroiditis de Hashimoto (TH) es una enfermedad autoinmune de la tiroides, asociada con bocio e hipotiroidismo. Aunque existe una clara relación entre TH y linfomas de la tiroides, la relación entre TH y cáncer tiroideo no aparece clara. Con el fín de evaluar este asunto, hemos revisado en forma retrospectiva tanto los informes de patología de todos los especímenes de tiroidectomía, así como las historias clínicas de los pacientes admitidos al Centro Médico de la Universidad de Michigan, Ann Arbor, Michigan, con el diagnóstico de TH o de tiroiditis linfocítica crónica (TLC) en un período de 10 años (1975-1985). Se registraron 809 diagnósticos patológicos de 816 especímenes de tiroidectomía en 793 pacientes. Además, se dispuso de 180 
de 228 historias clínicas para revisión. Sólo 128 pacientes satisficieron nuestros criterios para el diagnóstico de TH. TH o TLC fueron diagnosticadas en $147(18.2 \%)$ de 809 de los especímenes tiroideos. La TH ocurrió en forma concurrente con el cáncer tiroideo en $24 \%$ de todos los casos de $\mathrm{TH}$, en tanto que la TH ocurrió en forma concurrente con enfermedad benigna de la tiroides en $71 \%$ de la totalidad de los casos de TH en todos los especímenes tiroideos. Se encontraron $111(87 \%)$ mujeres y $17(13 \%)$ hombres de 128 pacientes cuyas historias clínicas fueron revisadas: la edad promedio fue $49 \pm 14$ años. Noventa y ocho $(77 \%)$ de los pacientes presentaban bocio y 57 $(45 \%)$ presentaban masas tiroideas dominantes, de las cuales 38 (67\%) eran nódulos solitarios. Un paciente $(0.8 \%)$ se presentó con parálisis del nervio recurrente laríngeo y $12(9 \%)$ con compresión traqueal. Sólo $29(38.2 \%)$ de 76 pacientes investigados tenían títulos positivos de ATG, mientras 65 (87\%) de 75 tenían títulos AM positivos. Setenta (55\%) fueron evaluados mediante escanografía con tecnecio o con ${ }^{131} \mathrm{I}$; se observó un patrón heterogéneo en la gamagrafía en $75 \%$ de ellos. Noventa y uno $(71 \%)$ fueron tratados inicialmente con supresión tiroidea. Sin embargo, 27 (21\%) requirieron tiroidectomía en su manejo inicial. Al final $60 \%$ requirieron tiroidectomía y $37 \%$ no la requirieron. $\mathrm{La}$ indicación mayor para intervención quirúrgica fue la presencia de una masa dominante en $40(52 \%)$ de 77 pacientes. Sólo $17(13 \%)$ pacientes exhibieron cáncer tiroideo concomitante con TH y $3(2 \%)$ presentaron linfoma con TH. La incidencia de cáncer mínimo (oculto) en un estudio de 100 autopsias consecutivas en nuestra institución fue $13 \%$. Consideramos que estos datos sugieren que la relación entre TH y cáncer tiroideo es apenas relativa, en el mejor de los casos. Será necesario hacer el seguimiento prospectivo de un grupo grande de pacientes con $\mathrm{TH}$ y de un grupo control sin $\mathrm{TH}$ para detectar la incidencia de cáncer tiroideo en cada grupo para poder enfocar en forma apropiada este asunto.

\section{Acknowledgment}

We are grateful to Stacy Wilkinson for the preparation of this manuscript.

\section{References}

1. McConahey, W.M.: Hashimoto's thyroiditis. Med. Clin. North Am. 56:885, 1972

2. Holm, L.E., Blomgren, H., Lowhagen, T.: Cancer risks in patients with chronic lymphocytic thyroiditis. N. Engl. J. Med. 312:601, 1985

3. Lindsay, S., Dailey, M.E.: Malignant lymphoma of the thyroid gland and its relation to Hashimoto's disease: A clinical and pathologic study of 8 patients. J. Clin. Endocrinol. Metab. 15:1332, 1955

4. Ott, R.A., McCall, A.R., McHenry, C., Jarosz, H., Armin, A., Lawrence, A.M., Paloyan, E.: The incidence of thyroid carcinoma in Hashimoto's thyroiditis. Am. Surg. 53:442, 1987

5. Dailey, M.E., Lindsay, S., Skahen, R.: Relation of thyroid neoplasms to Hashimoto's disease of the thyroid gland. Arch. Surg. $70: 291,1955$
6. Chesky, V.E., Hellwig, C.A., Welch, J.W.: Cancer of the thyroid associated with Hashimoto's disease: An analysis of forty-eight cases. Am. Surg. 28:678, 1962

7. Crile, Jr., G., Hazard, J.B.: Incidence of cancer in struma lymphomatosa. Surg. Gynecol. Obstet. 115:101, 1962

8. Crile, Jr., G.: Struma lymphomatosa and carcinoma of the thyroid. Surg. Gynecol. Obstet. 147:350, 1978

9. Hirabayashi, R.N., Lindsay, S.: The relation of thyroid carcinoma and chronic thyroiditis. Surg. Gynecol. Obstet. 121:243, 1965

10. Holmes, Jr., H.B., Kreutner, A., O'Brien, P.H.: Hashimoto's thyroiditis and its relationship to other thyroid diseases. Surg. Gynecol, Obstet. 144:887, 1977

11. Pollock, W.F., Sprong, Jr., D.H.: The rationale of thyroidectomy for Hashimoto's thyroiditis: A premalignant lesion. West. J. Surg. Obstet. Gynecol. 66:17, 1958

12. Schlicke, C.P., Hill, J.E., Schultz, G.F.: Carcinoma in chronic thyroiditis. Surg. Gynecol. Obstet. 111:552, 1960

13. Shands, W.C.: Carcinoma of the thyroid in association with struma lymphomatosa (Hashimoto's disease). Ann. Surg. 151:675, 1960

14. Woolner, L.B., McConahey, W.M., Beahrs, O.H.: Struma lymphomatosa (Hashimoto's thyroiditis) and related thyroidal disorders. J. Clin. Endocrinol. Metab. 19:53, 1959

15. Kidd, A., Okita, N., Row, V.V., Volpe, R.: Immunologic aspects of Graves' and Hashimoto's diseases. Metabolism 29:80, 1980

16. Strakosch, C.R., Wenzel, B.E., Row, V.V., Volpe, R.: Immunology of autoimmune thyroid diseases. N. Engl. J. Med. 307:1499, 1982

17. Siegel, S.: Nonparametric Statistics for the Behavioral Sciences, New York, McGraw-Hill Book Co., Inc., 1956, pp. 104-111

18. Nishiyama, R.H., Ludwig, G.K., Thompson, N.W.: The prevalence of small papillary thyroid carcinomas in 100 consecutive necropsies in an american population. In Radiation-Associated Thyroid Carcinoma, J.L. DeGroot, editor, New York, Grune \& Stratton, 1977, pp. 123-135

19. Beierwaltes, W.H.: The most common thyroid disease in the state of Michigan is endemic goiter not due to iodine deficiency. Washtenaw County Med. Soc. Bull. 39:3, 1987

20. Thomas, Jr., C.G., Rutledge, R.G.: Surgical intervention in chronic (Hashimoto's) thyroiditis. Ann. Surg. 193:769, 1981

21. Masi, A.T.: Hashimoto's disease: An epidemiological study based on a community-wide hospital survey. J. Chron. Dis. 18:35, 1965

22. Furszyfer, J., Kurland, L.T., McConahey, W.M., Shah, K.H., Lawrence, A.M., Paloyan, E.: Epidemiologic aspects of Hashimoto's thyroiditis and Graves' disease in Rochester, Minnesota (1935-1967), with special reference to temporal trends. Metabolism 21:197, 1972

23. Mauras, N., Zimmerman, D., Goellner, J.R.: Hashimoto's thyroiditis associated with thyroid cancer in adolescent patients. J. Pediatr. 106:895, 1985

24. Allison, A.C.: Self-tolerance and autoimmunity in the thyroid. N. Engl. J. Med. 295:821, 1976

25. Clark, O.H., Greenspan, F.S., Dunphy, J.E.: Hashimoto's thyroiditis and thyroid cancer: Indications for operation. Am. J. Surg. 140:65, 1980

26. Ott, R.A., Calandra, D.B., McCall, A., Woolnet, L.B., Elveback, L.R.: The incidence of thyroid carcinoma in patients with Hashimoto's thyroiditis and solitary nodules. Surgery 98:1202, 1985

27. Clark, O.H.: Thyroid and parathyroid. In Surgical Diagnosis and Treatment, J.E. Dunphy, L.W. Way, editors, Los Altos, Lange Medical, 1977, pp. 254-70

28. Hoffman, G.L., Thompson, N.W., Heffron, C.: The solitary thyroid nodule: A reassessment. Arch. Surg. 105:379, 1972

29. Lividas, D., Psarras, A., Koutras, D.A.: Malignant cold thyroid nodules in hyperthyroidism. Br. J. Surg. 63:726, 1976

30. Clark, O.H., Okerlund, M.D., Cavalleri, R.R., Greenspan, F.S.: Diagnosis and treatment of thyroid, parathyroid and thyroglossal duct cysts. J. Clin. Endocrinol. Metab. 48:983, 1979 